\title{
WEBSITES AS A EUROREGIONAL MARKETING TOOL IN POLAND
}

\author{
TOMASZ STUDZIENIECKI $^{1}$, CORINA TATAR ${ }^{2}$ \\ 1 Gdynia Maritime University \\ Faculty of Entrepreneurship and Quality Science \\ e-mail: tomaszstudzieniecki@wp.pl \\ 2 University of Oradea \\ Faculty Geography, Tourism and Sports \\ e-mail: corina_criste_78@yahoo.com
}

\begin{abstract}
\begin{tabular}{l|l} 
JEL CODES & M31, R50, 019
\end{tabular}
KEYWORDS marketing, territorial, cross-border, Euroregion, internet

ABSTRACT This paper discusses territorial marketing of Euroregions. Websites, one of the marketing tools, were the subject of an analysis. Based on literature research and experiences of the authors, criteria for website assessment have been prepared and 14 Polish Euroregional entities were the subject of an empirical study. An expert binary analysis and a survey in which a group of Polish students participated were used in the study. The study has shown that the websites vary considerably by content, form and navigation. Euroregions with interesting, stylish and modern websites have been identified. These websites are more and more commonly used for territorial promotion, including tourist promotion. After relevant consultations and modifications, the assessment criteria and the research tools that were proposed by the authors can be used in research and can support Euroregional authorities in the improving of marketing communication tools.
\end{abstract}

\section{Introduction}

Websites are becoming an increasingly important tool for territorial marketing. A special case of territorial marketing is marketing of cross-border regions called Euroregions. This issue can rarely be found in academic literature. Using triangulation, the authors seek an answer to the question - what role is played by websites in marketing activities of Euroregions. 
The authors show the character of Euroregional marketing based on literature research. Furthermore, they develop research tools (an expert questionnaire and a survey questionnaire) for website assessment in terms of two complementary elements, i.e. content and form. The authors also seek to answer the questions - who the receivers of marketing activities are and what information is given to them. The subject of this study is 16 national Euroregional entities in Poland, including 14 entities which have their own websites.

A diagnostic survey was carried out based on a questionnaire. Fifty-four students took part in the survey. The study is supplemented by a binary expert analysis with 10 key criteria for assessment of Euroregional websites.

\section{"Euroregional" marketing and its character}

Euroregional marketing is inseparably connected with the process of cross-border cooperation. In operational terms, such a cooperation may be defined (Sousa, 2012, p. 5) as any type of concerted action between public or private institutions of the border regions of two (or more) states, driven by geographical, economic, cultural and political factors, with the objective of reinforcing neighbourhood relations, solving common problems or managing jointly resources between communities through any cooperation mechanisms available. The institutionalization of cross-border cooperation in Europe results in an establishment of international structures for cross-border cooperation called Euroregions (Kurowska-Pysz, Castanho, Gomez, 2018, p. 134).

Euroregion is not a legal term and it is defined ambiguously in source literature (Medeiros, 2011, p. 141). Apart from the term "Euroregion" words such as regio, euregio, euregion, europaregion, eurodistrict are used as synonyms (Duran, 2007, pp. 234-238). Leaving aside legal issues, Euroregion in an economic sense can be interpreted as a cluster (Greta, 2016, p. 34) or an institution (Perkmann, 2002, p. 113) that coordinates cross-border cooperation in its area of activity.

Euroregional authorities, just like regional authorities, may conduct marketing activities aimed at achieving the desired objectives by using available tools. Conventionally marketing conducted by Euroregional bodies can be called Euroregional marketing (Greta, Tomczak-Woźniak, 2014, pp. 329-339). But this term is so ambiguous that it needs to be specified more precisely. The organization and legal structure of Euroregions vary greatly among European countries. An important differentiating criterion is the degree of integration of national euroregional entities. In a Euroregion that covers two countries A and B (fig. 1) the aim is that marketing activities can be conducted by one cross-border entity $\mathrm{P}$ (A, B). However, in practice marketing activities are also conducted by national entities $\mathrm{P}(\mathrm{A})$ and $\mathrm{P}(\mathrm{B})$. This situation takes place also in Poland, where national Euroregional elements operate almost everywhere as associations of local governments. Each association, regardless of transnational structures, conducts its own "Euroregional marketing". 


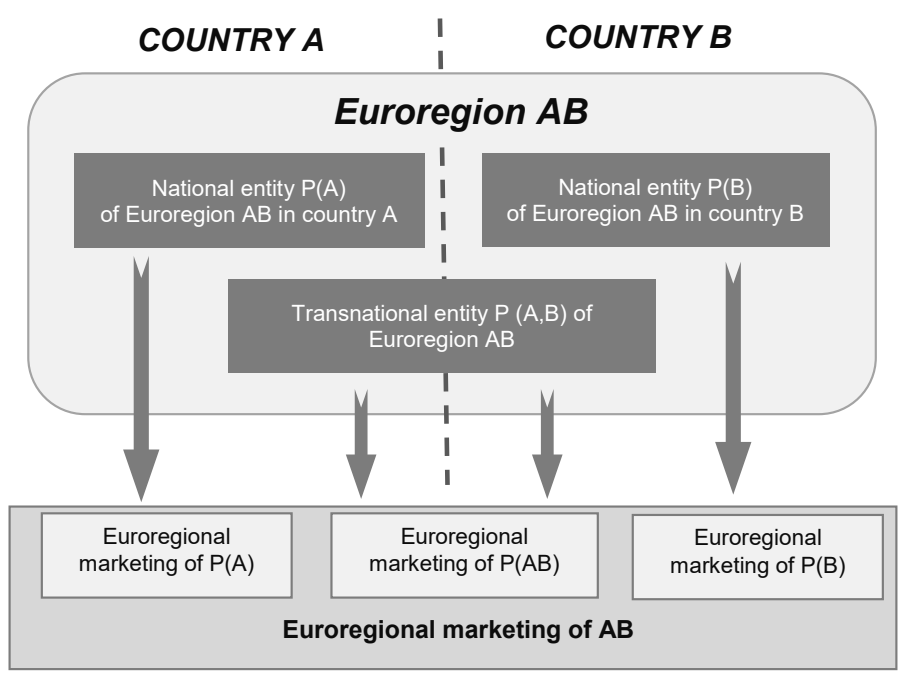

Figure 1. Marketing organizational model in Euroregions in Poland

Source: own study.

The philosophy of euroregional marketing evolved along with the development of crossborder cooperation. The first Euroregions were established in Poland in the 1990s. At that time Euroregional marketing was born (Winiarski, Przybyła, Bobowski, 1997, pp. 276-303). It was defined as "activities that create favourable conditions for Euroregional activity as well as the representation of euroregional interests at national level and the promotion of Euroregional ideas among local communities, aimed to make the entire population accept the objectives of cross-border cooperation". At first government administration was the initiator and coordinator of Euroregional marketing. Over time this function was taken over by local administration, mainly at communal level. Contemporary Euroregional marketing has become a part of territorial marketing (Greta, TomczakWoźniak, 2014, p. 332), including tourism marketing (Studzieniecki, 2003, p. 256; Studzieniecki, 2006 , p. 243) and investment marketing (Leszczyńska, 2005, p. 24). Its objective is to influence opinions and attitudes of external and internal stakeholders by developing an adequate set of means and instruments for stimulation of exchange relations.

\section{Wehsites as a marketing tool}

Creating websites is one of the more important elements of modern marketing activities conducted by organizations. A website is a collection of webpages scored on a particular computer, called a Web server, and accessed by outside computers (Bell, 2009, p. 9).

It is believed that websites are becoming (Wolniak, 2012, p. 884) a key source of information about the organization, a promotional tool and a PR tool. There are many paths which the organization follows to share information about itself and its activity as effectively as possible. It wants to be 
positively assessed by the Internet community. But there are also many risks and traps which have a negative impact on the functioning of the organization. These factors are analysed and assessed, seeking the most optimal communication tools (Grzywińska-Rąpca, Grzybowska-Brzezińska, 2016, p. 333).

The website content can be divided into a static part and a dynamic part. The former is a permanent element on the website, while dynamic elements include news, panels to log in and save preferences of each user. Furthermore, websites can contain interactive elements such as forms or interactive buttons (Wolniak, 2012, p. 886).

Before a website is created, it is necessary to connect it with the activity and image of the organization (Bell, 2009, p. 9). When designing and visualizing the website, the following principles must be applied (Frankowski, 2010, p. 67):

- a proper layout, a logical and clear structure of the content,

- a sensible sitemap, which makes finding the information one is looking for easier,

- a system of links - a navigation map,

- precise and up-to-date information about the website's owner,

- an accurate format of the text on the screen,

- adequate language versions,

- proper graphics that identifies the website's owner (colours, symbols, patterns),

- interactive elements, users can post their own opinions and comments,

- optionally a keyword search box.

The institution that is creating a website not only specifies the objective it wants to achieve by using this tool but also indicates target groups of receivers (Frankowski, 2010, p. 11). As for websites of Euroregions, three key groups of receivers can be identified (tab. 1).

Table 1. Key groups of receivers of Euroregional marketing in Poland.

\begin{tabular}{|l|l|l|}
\hline No. & \multicolumn{1}{|c|}{ Category } & \multicolumn{1}{|c|}{ Receivers } \\
\hline 1. & $\begin{array}{l}\text { Receivers who have their registered office or residence in the } \\
\text { area of activity }\end{array}$ & $\begin{array}{l}\text { Members (institutions) of the Euroregion } \\
\text { Citizens } \\
\text { Social and economic entities } \\
\text { Local government units }\end{array}$ \\
\hline 2. & $\begin{array}{l}\text { Receivers who have their registered office or residence outside } \\
\text { the area of activity }\end{array}$ & $\begin{array}{l}\text { Tourists } \\
\text { Potential citizens } \\
\text { Investors }\end{array}$ \\
\hline 3. & Others, regardless of their registered office or residence & $\begin{array}{l}\text { Academics } \\
\text { Students } \\
\text { Journalists } \\
\text { Entities interested in activity }\end{array}$ \\
\hline
\end{tabular}

Source: own study.

For high quality communication via websites, websites should be periodically evaluated. The scope of evaluation must include, above all, the content of the presented information, its clarity, topicality, easy navigation (browsing), website clarity and the usefulness of information for users (Smalec, 2014, p. 203). 
A popular method for assessment of websites of offices and administrations at different levels is the Website Attribute Evaluation System (WAES) prepared by the international team Cyberspace Policy Research (Bański, 2006, p. 60). The website content and functionality are assessed with 40 binary criteria. The WAES is often modified, some criteria are ignored or weights are ascribed to them (Prałat, 2010, p. 259). Websites of administration offices are sometimes assessed on a scale with several points (Smalec, 2014, p. 204). According to the authors of this paper, it is worth assessing websites by using a diagnostic survey with a questionnaire. This type of surveys, despite an element of subjectivity, gives the opportunity to confront better the content and form of a website with the expectations and preferences of the assessing persons.

\section{Euroregions in Poland}

There are 16 Euroregions located on Polish borders (fig. 2). They border all 7 neighbouring countries (Russia, Lithuania, Belarus, Ukraine, Slovakia, Czechia, Germany). Apart from the territories of the neighbouring countries, Euroregions include territorial units of four countries (Romania, Hungary, Sweden, Denmark).

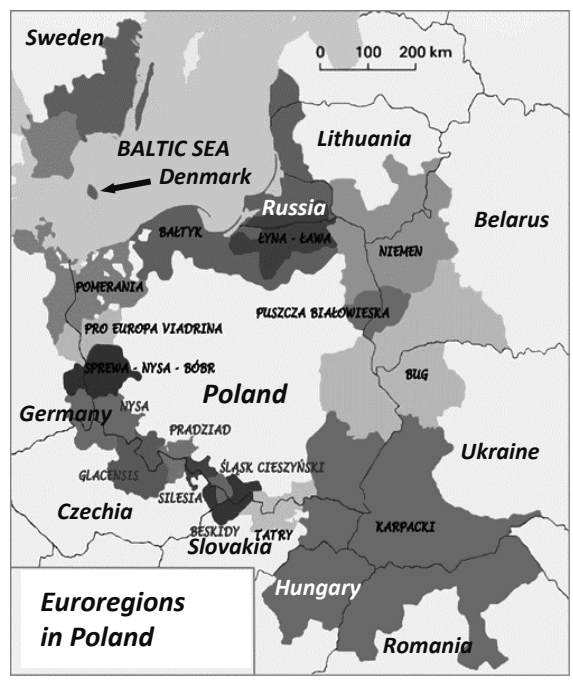

Figure 2. Euroregions in Poland

Source: own study.

The entities of the Euroregions (defined as international structures) are Polish national entities which operate as associations. At the time of conducting this study, only 14 entities have functioning websites. Internet domains consist of two parts: the main name and the ending - an extension. Most entities have the ending "PL" in their addresses. Only one entity has the "EU" ending (fig. 3). 


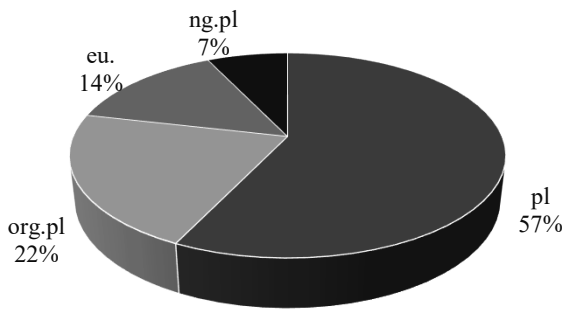

Figure 3. Endings of domains owned by national Euroregional entities in Poland

Source: own study.

The full Polish name of a Euroregion can be found in addresses of 10 entities (tab. 1). A shortened name or an abbreviation was used in the addresses of three entities. In one case it was the name of the association which belonged to the Euroregion instead of the name of the Euroregion (Olza). The address of Euroregion Białowieża Forest was http://www.euroregion-puszczabialowieska.prv. pl. However, when you entered this address, you were redirected into http://www.euroregion-pb.pl. Since none of these websites worked, they were not evaluated.

Table 2: Websites of national euroregional entities in Poland

\begin{tabular}{|c|c|c|c|c|c|}
\hline No. & $\begin{array}{l}\text { Euroregion } \\
\text { (in Polish) }\end{array}$ & Abbreviation & $\begin{array}{l}\text { Neighbouring } \\
\text { countries }\end{array}$ & $\begin{array}{l}\text { Name of the Polish entity } \\
\text { (in English) }\end{array}$ & Website \\
\hline 1. & Baltic & Bal & $\begin{array}{l}\text { Sweden, Denmark, } \\
\text { Lithuania, Russia }\end{array}$ & $\begin{array}{c}\text { Association of Polish } \\
\text { Communes Euroregion } \\
\text { Baltic }\end{array}$ & http://eurobalt.org.pl. \\
\hline 2. & Neman & Nie & Russia, Lithuania & $\begin{array}{c}\text { Association "Euroregion } \\
\text { Neman" }\end{array}$ & http://www.niemen.org.pl. \\
\hline 3. & Łyna- Ława & \multicolumn{4}{|c|}{ No website } \\
\hline 4. & Bug & Bug & Belarus, Ukraine & $\begin{array}{l}\text { Association of Local } \\
\text { Governments of Euroregion } \\
\text { "Bug" }\end{array}$ & http://www.euroregionbug.pl \\
\hline 5. & $\begin{array}{l}\text { Białowieża } \\
\text { Forest }\end{array}$ & \multicolumn{4}{|c|}{ Website breakdown } \\
\hline 6. & Carpathian & Kar & $\begin{array}{l}\text { Ukraine, Slovakia, } \\
\text { Hungary, Romania }\end{array}$ & $\begin{array}{l}\text { Association Carpathian } \\
\text { Euroregion Poland }\end{array}$ & http://www.karpacki.pl \\
\hline 7. & Tatras & Tat & Slovakia & $\begin{array}{c}\text { Association Euroregion } \\
\text { Tatras } \\
\end{array}$ & http://www.euroregion-tatry.eu \\
\hline 8. & Beskids & Bes & Slovakia & $\begin{array}{c}\text { Association } \\
\text { "Beskids Region" }\end{array}$ & http://www.euroregion-beskidy.pl/ \\
\hline 9. & $\begin{array}{c}\text { Śląsk } \\
\text { Cieszyński }\end{array}$ & $\mathrm{SC}$ & Czechia & $\begin{array}{c}\text { Association of Regional } \\
\text { Development and } \\
\text { Cooperation "Olza" }\end{array}$ & http://www.olza.pl/ \\
\hline 10. & Silesia & Sil & Czechia & $\begin{array}{c}\text { Association of Communes } \\
\text { of the Upper Odra River } \\
\text { Basin }\end{array}$ & http://www.euroregion-silesia.pl/ \\
\hline 11. & Pradziad & Pra & Czechia & $\begin{array}{c}\text { Association of Polish } \\
\text { Communes of Euroregion } \\
\text { Pradziad } \\
\end{array}$ & http://www.europradziad.pl \\
\hline
\end{tabular}




\begin{tabular}{|c|c|c|c|c|c|}
\hline No. & $\begin{array}{l}\text { Euroregion } \\
\text { (in Polish) }\end{array}$ & Abbreviation & $\begin{array}{l}\text { Neighbouring } \\
\text { countries }\end{array}$ & $\begin{array}{l}\text { Name of the Polish entity } \\
\text { (in English) }\end{array}$ & Website \\
\hline 12. & Glacensis & Gla & Czechia & $\begin{array}{c}\text { Association } \\
\text { of Polish Communes } \\
\text { of Euroregion Glacensis }\end{array}$ & http://euroregion-glacensis.ng.pl \\
\hline 13. & Nysa & Nys & Czechia, Germany & $\begin{array}{c}\text { Association of Polish } \\
\text { Communes of Euroregion } \\
\text { Nysa }\end{array}$ & http://www.euroregion-nysa.eu \\
\hline 14. & $\begin{array}{l}\text { Sprewa Nysa } \\
\text { Bóbr }\end{array}$ & SNB & Germany & $\begin{array}{l}\text { Association of Polish } \\
\text { Communes Euroregion } \\
\text { "Sprewa-Nysa-Bóbr" }\end{array}$ & http://euroregion-snb.pl \\
\hline 15. & $\begin{array}{l}\text { Pro Europa } \\
\text { Viadrina }\end{array}$ & PEV & Germany & $\begin{array}{l}\text { Association of Polish } \\
\text { Communes of Euroregion } \\
\text { "Pro Europa Viadrina" }\end{array}$ & http://www.euroregion-viadrina.pl/ \\
\hline 16. & Pomerania & Pom & Germany & $\begin{array}{c}\text { Association of Polish } \\
\text { Communes of Euroregion } \\
\text { Pomerania }\end{array}$ & http://www.pomerania.org.pl/ \\
\hline
\end{tabular}

Source: own study based on websites.

\section{Wehsite evaluation}

Based on literature research and the results of an analogous evaluation of websites of local government administration, the authors, using their own experience, proposed 10 criteria for website assessment (tab. 3). Based on these criteria they carried out a binary analysis.

Table 3. Website evaluation with the expert method

\begin{tabular}{|l|c|c|c|c|c|c|c|c|c|c|c|c|c|c|c|c|}
\hline No. & Elements & Bal & Nie & Bug & Kar & Tat & Bes & SC & Sil & Pra & Gla & Nys & SNB & PEV & Pom & Total \\
\hline 1. & members & + & + & + & + & + & + & + & + & + & + & + & + & + & + & 14 \\
\hline 2. & authorities & + & - & + & + & + & + & + & + & + & + & + & + & + & + & 13 \\
\hline 3. & employees & + & - & + & - & - & + & + & + & + & + & + & + & + & + & 11 \\
\hline 4. & statute & + & + & + & - & + & + & + & + & + & + & + & + & + & + & 13 \\
\hline 5. & contact & + & + & + & + & + & + & + & + & + & + & + & + & + & + & 14 \\
\hline 6. & background & + & + & + & + & + & + & + & + & + & + & + & + & + & + & 14 \\
\hline 7. & reports & + & + & + & + & - & - & + & - & + & - & + & - & - & - & 7 \\
\hline 8. & $\begin{array}{c}\text { current } \\
\text { activities }\end{array}$ & + & + & + & + & + & + & + & + & + & + & + & + & + & + & 14 \\
\hline 9. & $\begin{array}{c}\text { ongoing } \\
\text { projects }\end{array}$ & + & + & + & + & + & + & + & + & + & + & + & + & + & + & 14 \\
\hline 10. & $\begin{array}{c}\text { place } \\
\text { promotion }\end{array}$ & + & - & + & + & + & + & + & + & + & + & + & + & + & + & 13 \\
\hline Total & & 10 & 7 & 10 & 8 & 8 & 9 & 10 & 9 & 10 & 9 & 10 & 9 & 9 & 9 & $\mathrm{X}$ \\
\hline
\end{tabular}

Source: own study.

In 5 out of 14 Euroregions, the websites contained all 10 elements. All the websites included elements such as members, contact, background, current activities and ongoing projects. Nearly all Euroregions made their statutes available on their websites. Only some of the Euroregions put financial and substantive reports on their websites. But we must emphasize that it is not their obligation. Almost all the websites were used for tourist and promotional purposes. When analysing 
the activity of Euroregions, it was noticed that they fulfil one more important function. They share information about programmes and funds dedicated to cross-border cooperation and help to match partners to implement cross-border projects.

The websites were also examined by using a moderated survey. Fifty-four students took part in it. They viewed, tested and assessed the websites on a scale from 1 to 10 with the participation of a moderator. Five categories were assessed (table 4). The accuracy of the address got the highest score and visual attractiveness received the lowest score. The address which consisted of the full name of a Euroregion and the ending "PL" got the highest score (e.g. www.euroregionbug.pl). The address of Euroregion Cieszyn Silesia obtained the lowest score (4.53). It probably resulted from the fact that the name of the address included not the name of the Euroregion but the association Olza which is a part of this Euroregion (http://www.olza.pl). The category - visual attractiveness had the most diversified scores (from 4.28 to 8.81 ), while the category - easy navigation had the least diversified score (from 6.16 to 8.24). The websites were on average assessed as good (7.08). One of the websites (Euroregion Beskids) was assessed as very good (8.47). At the other end, the website of Euroregion Neman got the lowest score (5.75).

Table 4. Website evaluation with a questionnaire

\begin{tabular}{|c|c|c|c|c|c|c|c|}
\hline No. & Euroregion & $\begin{array}{l}\text { Accuracy } \\
\text { of address }\end{array}$ & $\begin{array}{l}\text { Website } \\
\text { layout }\end{array}$ & $\begin{array}{c}\text { Easy } \\
\text { navigation }\end{array}$ & $\begin{array}{c}\text { Visual } \\
\text { attractiveness }\end{array}$ & $\begin{array}{c}\text { Substantive } \\
\text { attractiveness }\end{array}$ & Average \\
\hline 1. & Baltic & 7.83 & 7.02 & 7.20 & 6.83 & 6.98 & 7.17 \\
\hline 2. & Niemen & 7.68 & 4.94 & 6.22 & 4.28 & 5.64 & 5.75 \\
\hline 3. & Bug & 9.02 & 7.00 & 6.96 & 6.33 & 6.48 & 7.16 \\
\hline 4. & Carpathian & 7.72 & 6.83 & 6.83 & 6.43 & 7.00 & 6.96 \\
\hline 5. & Tatra & 8.36 & 7.39 & 7.26 & 7.19 & 6.96 & 7.43 \\
\hline 6. & Beskids & 8.68 & 8.43 & 8.24 & 8.81 & 8.17 & 8.47 \\
\hline 7. & $\begin{array}{c}\text { Śląsk } \\
\text { Cieszyński }\end{array}$ & 4.53 & 7.19 & 7.02 & 6.79 & 7.23 & 6.56 \\
\hline 8. & Silesia & 8.11 & 6.48 & 6.28 & 6.33 & 6.37 & 6.71 \\
\hline 9. & Pradziad & 7.96 & 5.91 & 6.16 & 5.72 & 6.11 & 6.37 \\
\hline 10. & Glacensis & 7.77 & 6.93 & 7.65 & 7.57 & 7.52 & 7.49 \\
\hline 11. & Nysa & 8.33 & 7.13 & 7.50 & 6.92 & 7.52 & 7.48 \\
\hline 12. & Sprewa Nysa Bóbr & 6.94 & 7.04 & 7.31 & 7.31 & 7.54 & 7.43 \\
\hline 13. & $\begin{array}{c}\text { Pro Europa } \\
\text { Viadrina }\end{array}$ & 7.65 & 7.11 & 7.13 & 7.19 & 7.24 & 7.27 \\
\hline 14. & Pomerania & 7.78 & 6.71 & 7.06 & 7.10 & 7.00 & 7.13 \\
\hline 15. & Average & 7.74 & 6.87 & 7.06 & 6.77 & 6.98 & 7.08 \\
\hline
\end{tabular}

Source: own study.

The survey has also revealed an interesting correlation between the score of visual attractiveness and substantial attractiveness of Euroregions. The website that obtained the highest score in substantive attractiveness (Euroregion Beskids) also got the highest score in visual attractiveness. 


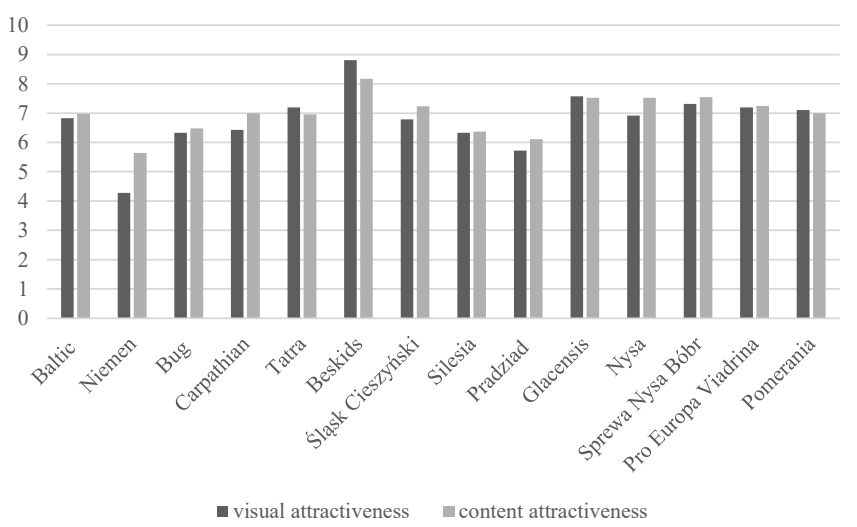

Figure 4. Visual and substantive attractiveness of websites of Polish Euroregions

Source: own study.

\section{Conclusions}

The issue of euroregional marketing, in the context of evolution of Euroregions and development of their successors, i.e. European Groupings of Territorial Cooperation, seems to be important and far-reaching. Euroregions, and more precisely national entities of Euroregions, operate in Poland as associations of local governments, which determine their activities and indirectly impose the content and form of their websites. There is no perfect example of what the website of a Euroregion should look like and what it should contain. Numerous models and patterns developed for the needs of local government administration are not fully applicable for Euroregions. The authors of this paper proposed important elements which, in their opinion, a website should contain. Having conducting a survey in Poland, they noticed that majority of these elements is already present on the websites of Euroregions. Many Euroregions have very stylish, modern and interesting websites. They can serve as a model for other Euroregions. After adequate consultations and modifications the assessment criteria and research tools proposed by the authors can be used universally.

Cross-border cooperation and Euroregions are still rather unknown in Central and Eastern Europe, so Euroregional authorities perform an educational function via their websites. Euroregions are a link in the system of sharing information about programmes and funds dedicated to crossborder cooperation. They are important for matching partners to implement cross-border projects.

It should be stressed that websites are more and more commonly used for regional promotion. Consumers of euroregional products are both tourists and citizens. Websites are used in very different ways for tourist promotion. The simplest form is a picture gallery (Euroregion Beskids), the most advanced one is a promotional video (Euroregion Silesia), an event calendar (Euroregion Glacensis) or a separate tourist website (Euroregion Cieszyn Silesia). Taking into account the fact that members of Euroregions (mainly communes) and regional authorities conduct their own marketing activities and have their own websites, it is challenging to synchronize Euroregional marketing in such a way that its effects are optimized and synergetic benefits are generated. 


\section{References}

Bański, J. (2006). Witryny internetowe jednostek samorządowych z siedzibą w małych miastach - analiza i ocena. Studia Obszarów Wiejskich, 11, 59-72.

Bell, M. (2009). Build a website for free. London: Pearson Education.

De Sousa, L. (2012). Understanding European Cross-border Cooperation: A Framework for Analysis. Journal of European Integration, 1, 1-9.

Duran, I. D. (2007). Regions and Euroregions. The Journal of the Faculty of Economics - Economic Science Series, 1, 234-238.

Frankowski, P. (2010). Firmowa strona WWW. Idee, strategia, realizacja. Gliwice: Wydawnictwo Helion.

Greta, M. (2016). Euroregion in the role of management of structural aid and as a natural cluster. Organizacja i Zarzadzanie, $63,33-43$.

Greta, M., Tomczak-Woźniak, E. (2014). Euroregion jako przykład marketingu połączonego (terytorialnego, lokalnego i regionalnego) na wybranym przykładzie. Przedsiębiorczość i Zarządzanie, 6 (15), 329-339.

Grzywińska-Rąpca, M., Grzybowska-Brzezińska, M. (2016). Rola Internetu w realizacji działań marketingowych firmy i zdobywaniu nowych segmentów klientów. Collegium of Economic Analysis Annals, 40, 333-342.

Kurowska-Pysz, J., Castanho, R. A., Gomez, J.M.N. (2018). Cross-border cooperation - the barriers analysis and the recommendations. Polish Journal of Management Studies, 2 (17), 134-147.

Leszczyńska, K. (2005). Bezpośrednie inwestycje zagraniczne na terenie polskich euroregionów. Handel Wewnętrzny, 6, 24-26.

Medeiros, E. (2011). (Re)defining the Euroregion Concept. European Planning Studies, 1 (19), 141-158.

Perkmann, M. (2002). Euroregions: institutional entrepreneurship in the European Union. In: M. Perkmann, N. Sum (eds.), Globalization, regionalization, and cross-border regions (pp. 113-139). Basingstoke: Palgrave MacMillan.

Prałat, E. (2010). Strony internetowe polskich gmin. In: R. Knosala (ed.), Komputerowo zintegrowane zarzadzanie (pp. 259-268). Opole: Oficyna Wydawnicza Polskiego Towarzystwa Zarządzania Produkcją.

Przybyła, Z. (1995). Zagadnienia marketingu euroregionalnego (na przykładzie euroregionu „Nysa”). In: A. Stasiak, K. Mirosa (eds.), Polska i jej współdziałanie transgraniczne z sąsiadami (pp. 105-109). Warsaw: Polska Akademia Nauk. Instytut Geografii i Przestrzennego Zagospodarowania.

Smalec, A. (2014). Analiza witryn internetowych wybranych miast wojewódzkich. Problemy Zarządzania, Finansów i Marketingu, 33, 199-210.

Studzieniecki, T. (2003). Sports tourism model - a compromise between social needs and marketing demands. In: P. Keller, T. Bieger (eds.), Publication of the AIEST, 53rd Congress, Athens, Greece, 2003., "Sport and Tourism", 45 (pp. 247-262). St. Gallen: Editions AIEST.

Studzieniecki, T. (2006). Tourism marketing in transborder regions. In: P. Keller, T. Bieger (eds.), Marketing efficiency in tourism (pp. 243-255). Berlin: ESV.

Winiarski, B., Przybyła, Z., Bobowski, Z. (1997). Rola współpracy transgranicznej w rozwoju lokalnym i regionalnym (na przykładzie województw zachodnich). Studia Regionalne i Lokalne, 19 (52), 276-303.

Wolniak, R. (2012). Funkcjonowanie witryn internetowych jako narzędzia marketingowego w przedsiębiorstwach przemysłowych. In: R. Knosala (ed.), Innowacje w inżynierii produkcji (pp. 884-892). Opole: Oficyna Wydawnicza Polskiego Towarzystwa Zarządzania Produkcją. 


\section{WITRYNA INTERNETOWA JAKO NARZĘDZIE MARKETINGU EUROREGIONALNEGO W POLSCE}

\author{
SŁOWA KLUCZOWE \\ STRESZCZENIE
}

marketing, terytorialny, transgraniczny, euroregion, Internet

Artykuł podejmuje problematykę marketingu terytorialnego euroregionów. Analizie poddano jedno z narzędzi marketingowych jakim jest witryna internetowa. Na podstawie studia literaturowych i doświadczeń autorów opracowano kryteria oceny witryn internatowych i przeprowadzono badania empiryczne 14 narodowych podmiotów euroregionalnych w Polsce. W badaniach wykorzystano metodę binarnej analizy eksperckiej oraz sondażu ankietowego przeprowadzonego na grupie studentów polskich. Badania dowiodły znacznego zróżnicowania witryn internetowych pod względem treści, formy i nawigacji. Wskazano euroregiony posiadające ciekawe, eleganckie, i nowoczesne witryny. Witryny te znajdują coraz większe zastosowanie w promocji terytorialnej, w tym w promocji turystycznej. Zaproponowane przez autorów kryteria oceny i narzędzia badawcze, po stosownych konsultacjach i modyfikacjach, mogą zostać wykorzystane w badaniach naukowych oraz ułatwić władzom euroregionalnym doskonalenie narzędzi komunikacji marketingowej. 